Near finalised version of: D A Higon, O Deniz, J Clegg, I Grugulis, S Salis, N Vasilakos and A M Williams (2010), 'The determinants of retail productivity: a critical review of the evidence', International Journal of Management Reviews, v12(2): 201 - 217

\title{
The determinants of retail productivity: A critical review of the evidence
}

Dr Dolores Añón Higón, Lecturer in Economics, Universidad de Valencia, Dpt. Estructura Económica, Facultad de Ecomomía, Avda. dels Tarongers, S/N, 46022 - Valencia, Spain. Email: M.Dolores.Anon@uv.es

Dr Ödül Bozkurt, Lecturer. Department of Organisation Work and Technology, Lancaster University Management School. Lancaster. LA1 4YX. United Kingdom. Tel. + 1524 594050; E-mail: o.bozkurt@lancaster.ac.uk

Professor Jeremy Clegg, Jean Monnet Professor of European Integration and International Business Management. Centre for International Business, University of Leeds (CIBUL), Leeds University Business School, Maurice Keyworth Building, University of Leeds, Leeds, West Yorkshire. LS2 9JT. United Kingdom. Tel.: +44 (0)113 343 4512; E-mail:

ljc@lubs.leeds.ac.uk

*Professor Irena Grugulis, Professor of Employment Studies. Bradford University School of Management, Emm Lane, Bradford, West Yorkshire. BD9 4JL. United Kingdom. Tel.: +44

(0)1274 234331; E-mail: I.Grugulis@bradford.ac.uk

Dr Sergio Salis, Research Fellow. Policy Studies Institute, 50 Hanson Street, London. W1W 6UP. United Kingdom. Tel.: +44 (0)20 7911 7506; E-mail: S.Salis@ psi.org.uk

Dr Nicholas Vasilakos, Research Fellow. Department of Economics, University of Birmingham, Birmingham. B15 2TT. United Kingdom. Tel. +44 (0)121 414 6740; E-mail: N.Vasilakos@bham.ac.uk

Professor Allan M. Williams, Professor of European Integration and Globalization. London Metropolitan University, Tower Building, 166-220 Holloway Road, London. N7 8DB. United Kingdom. Tel.: +44 (0) 171332914; E-mail: Allan.Williams@londonmet.ac.uk

*Corresponding author 


\title{
The determinants of retail productivity: A critical review of the evidence ${ }^{1}$
}

\begin{abstract}
This paper discusses the literature on the established determinants of productivity in the retail sector. It also draws attention to some neglected strands of research which provide useful insights into strategies that could allow productivity enhancements in this area of the economy. To date, very few attempts have been made to integrate different specialisms in order to explain what drives productivity in retail. Here we rectify this omission by putting together studies from economics, geography, knowledge management and employment studies. It is our view that quantitative studies of retail productivity should focus on total factor productivity in retailing as the result of competition/composition effects, planning regulations, ICT, the multinational operation element and workforce skills. Further, the fact that retail firms possess advantages that are transferable between locations, suggests that investment in strategies enhancing the transfer of explicit and tacit knowledge between and within businesses are crucial to achieve productivity gains.
\end{abstract}

\footnotetext{
${ }^{1}$ The review is part of a project within the Engineering and Physical Sciences Research Council (EPSRC) Productivity Ideas Factory, directed by the Advanced Institute of Management (AIM) (grant number: EP/D01350X/1). Thanks are due to participants in the IDEAS workshops for offering constructive comments on earlier versions of this paper. The usual disclaimers apply.
} 


\section{Introduction}

This review examines what is is known about productivity, and the factors that promote and inhibit it, in the retail sector. It is part of a larger Engineering and Physical Sciences (EPSRC) funded programme on productivity, under the auspices of the Advanced Institute of Management (AIM). Retailing is a major contributor to many economies. In mature developed economies the sector is typically the third largest services based industry (DTI 2004). Not surprisingly, given the importance of retailing, the productivity of the sector has become a focus of policy debate in recent years. Several comparative studies, at an aggregate level, have shown a labour productivity gap between countries, notably between France and the USA on one side and the UK on the other (McKinsey 1998, O'Mahony and de Boer 2002, van Ark et al. 2003). This gap persists even when measured in terms of hours worked, ranging from 10 to 63 per cent greater in the USA and 25 to 59 per cent greater in France (DTI 2004:33, ESRC 2004). The Templeton Report (2004) identifies a number of methodological issues in such comparisons: some are generic to most comparative studies, while others are specific to retailing (and some other services) for several reasons, including the blurring of outcomes and processes.

It is not only the measurement of the international productivity gap which is of interest, but also the specific factors that determine this. In a seminal contribution, Hall et al (1961) claim that three environmental factors, average income per head, population density and the rate of growth of the population, influence the scale of retail enterprise and the productivity

differential between British and North American retailers. More recently, Griffith et al. 
(2003) distinguish poor management, a lower skilled labour force, an inadequately competitive retail market, land regulation/planning differences, and the adoption and use of ICT as the factors behind lower productivity in the UK compared to the USA.

Our analysis discusses the validity of this argument, by presenting and evaluating available evidence about the impact of skills and knowledge transfer, competition, planning regulation, information and communication technology and internationalisation on the growth of retail total factor productivity. We argue that all five factors are important determinants of productivity performance and should be treated accordingly in related quantitative studies.

This review is informed, first, by the increasing internationalisation of retailing. Research shows that foreign owned multinational enterprises have a growing presence even in mature, largely consolidated markets like the UK (Burt and Sparks 2003:501), although some attempts in this direction have ended in market failure, underscoring the significance of the "societal embeddedness" of retailers and the retail business. (Wrigley and Lowe 2007: 33839). Wal-mart's withdrawal from the German market (Christopherson 2007) and Carrefour's exit from Japan (Aoyama 2007) are two high-profile examples of this. In general, however, the pace of the expansion of retail multinationals into emerging markets since the late 1990s has been rapid (Coe and Wrigley 2007). The productivity returns to different forms of ownership are complex, and the relationship has to be investigated specifically for retailing since the internationalisation process in the sector differs from manufacturing around several core factors and needs to be conceptualised seperately (Dawson 2007). 
Secondly, we consider research that comprehends the role of knowledge as a resource to be transferred, identifying key elements in intra- as opposed to inter-firm knowledge transfers, as well as knowledge creation. This leads us to focus on studies of the different types of knowledge in retail firms, as well as in jobs. It also links with our third point on retail skills, and we argue that there is a need for a closer examination of the real-life processes whereby skills are "applied" and measured in actual workplaces. Fourth, an increasing volume of studies tends to highlight the close and positive impact of the use of Information and Communication Technologies on retail productivity performance, a sector that untill recently was often criticised as being a low-tech employer of casual and unskilled labour. We outline the mechanism through which such a positive relationship may exist, while drawing attention to some recent empirical evidence. Finally, the role of planning regulation is discussed and evidence is presented of it being negatively related with retail productivity performance.

In the following sections we begin by discussing the measurement issues pertaining to productivity in retailing, as they manifest themselves in econometric analysis. We then review what are generally considered to be the key determinants of retail productivity: competition and composition effects, planning regulations, information and communications technologies, the multinational operation element and workforce skills This leads us to a more detailed discussion of the roles of knowledge transfer, skills and multinational enterprises, before we conclude by suggesting directions for future research on productivity. 


\section{Methodological and Measurement Issues in Assessing Productivity in Retailing}

There is a long-established discussion of the methodological issues involved in measuring productivity in the service sector in general, and of retailing in particular (for example, Cox 1948, Goodman 1985, Borin and Farris 1990, Reardon and Vida 1998, McGoldrick 2002). First, we consider some of the general issues relating to productivity in retailing, and then review the measurement of outputs and inputs.

There are specific problems associated with the methodologies traditionally used to measure productivity, based on growth accounting (following Solow 1956). The methods that have evolved within this framework were designed to analyse the manufacturing sector, which is relatively homogeneous. Retailing, by contrast, exhibits striking intra- and international diversity (Dawson 2004). It tends to have lower barriers to entry and exit than manufacturing, and attracts a large mass of small to medium-sized and family enterprises, whose owners and managers have very diverse objectives (e.g. self-employment or flexible working hours). It is very difficult to incorporate these objectives into conventional measures of productivity, such as volume of sales or profits per worker. International comparisons are even more problematic as firms tend to adjust their output-service mix to reflect the peculiarities of local markets (Kamakura et al. 1996). An alternative is provided by econometric analysis which estimates an explicitly specified production or cost function with the objective of establishing the direct linkage between productivity and the key characteristics or parameters of these functions. This is used to derive an index of productivity growth, and allows for the careful testing of various features of a postulated model, as opposed to a priori assumptions. The 
measurement of parameters can, however, be problematic and the quality of the results depends on the appropriateness of the functional form and the accuracy of the the methods chosen (Nadiri 1970).

The most commonly used measure of retail productivity is labour productivity (see Table 1), the ratio between a measure of output (frequently sales or gross value added) and a measure of labour (the number of employees or man-hours worked). It is of course vulnerable to the implicit assumption that there is only a single factor of production, labour, and ignores the role of physical capital, land and other factors. Recent empirical evidence underlines the validity of this concern. In 1995 the UK had lower labour productivity in retail than the USA and France, but its capital productivity was significantly higher (McKinsey 1998).

\section{(Table 1 here)}

Conceptually, total factor productivity (TFP) provides a more refined measure of productivity, being the ratio between real output and a weighted sum (reflecting their relative importance) of real factor inputs. There are two theoretically distinct methods for computing the index of inputs: the growth accounting approach predicts that, under some simplifying assumptions, factor income shares indicate appropriate weights; and the econometric method, which uses regression to identify weights. Both methods are constrained by the tangibility of inputs, in the sense that some inputs are difficult to quantify (such as organizational capital and knowledge). These can be represented by observable proxy variables, which are highly correlated with the unobservable inputs (e.g. human capital stock as a proxy for knowledge), 
but data availability may also be constrained for such proxies, especially at higher levels of data disaggregation.

There are a number of other problems in measuring productivity in retailing. First, retailing has a significantly seasonal demand which may be poorly represented in secondary data where - as is often the case - these are collected as "snapshots" at one moment in the year. And there are particular problems in identifying casual or part-time employment in many secondary data sources, both of which are characteristic of retailing. Second, in imperfectly competitive retail markets, prices do not necessarily reflect the quality (or cost) of the service; as retailing is often characterised by national regulation which limits competition, this makes cross-national comparative studies problematic. Third, market rigidities (such as tight planning regulation and strong labour unions) may distort the compensation of factors of production from their equilibrium values (Reynolds et al. 2005).

Fourth, there are technical issues such as "aggregation bias", or the loss of variation, which are encountered when it proves necessary to aggregate across firms or sectors, especially where the loss of variance is not uniform across all independent variables, or between countries in a comparative analysis. These problems are particular acute in retailing because of its heterogeneity. Reynolds et al. (2005) also emphasise the difficulties involved in comparing superstores and convenience stores. Because the former are more capitalintensive, labour productivity measures tend to understate the total factor productivity of convenience stores. Fifth, one of the key measurement issues in the service sector relates to the importance of non-material outputs. The intangible nature and heterogeneity of outputs, 
the participation of customers in the production process, and the high degree of simultaneity between production and consumption (Goldman 2001), all pose significant definitional and measurement challenges in research on retailing.

The measurement of output is particularly challenging in retailing, and Reynolds et al. (2005) provide two examples of potential measurement problems that can bias productivity estimates. First, the difficulty of disentangling the products sold by a retailer and the retail services delivered. A typical example is the opening up of more tills in a convenience store to reduce customers' queuing time. Although this increases customer welfare it will be measured as a decline in productivity, since opening a new till reduces sales per cashier (unless the market share of the retailer increases as a result of the service improvement). This is related to the problem of quality adjustment: in retailing, the process of being served is as much a part of the purchase as any product exchanged (Hean et al. 2003). A second issue relates to the problems associated with using deflator indices. For example, Nakamura (1999) finds that the consumer price index over-estimates US inflation, between 1978 and 1996, by 1.4 per cent a year, resulting in underestimation of real output and, potentially, of labour productivity.

In summary, there is no consensus on how to guage output in retailing for the purpose of productivity measurement (Timmer and Inklaar 2005). Many productivity studies, particularly at the store level, use real sales (Doms et al. 2004) or gross margin (McKinsey 1998), defined as sales less the cost of goods sold. At a more aggregate level, and particularly in international or sectoral comparisons, gross output and value added (for instance 
O'Mahony and de Boer 2002, and Basu et al. 2003) are more frequently used. But none of these adequately engages with the intangible nature of retailing output (see Betancourt 2004).

There are also difficulties in measuring inputs (Griffith and Hamgart 2005). Adjustments are required for full-time versus part-time employees and for skills composition. This is not insignificant, because skills are an important determinant of the international productivity gap: for instance, the UK lags behind France and Germany in terms of intermediate skills, and behind the USA in graduate skills. There are also issues relating to the difference between labour productivity and total factor productivity. McKinsey (1998) shows that when factors of production other than labour are accounted for, the productivity gap for the food retailing sector between the UK and other European countries tends to narrow and, sometimes, disappears. Total factor productivity potentially allows the identification of inefficient use of non-labour factors of production, such as ICT, but data and resource constraints often do not permit full coverage and differentiation of inputs.

Finally, one somewhat surprising feature of UK retailing is the paucity of government collected statistics. The decennial Census of Distribution, which begun in 1951, was discontinued after 1971 and was instead replaced by the much more limited annual Retailing Inquiries. While the Census of Distribution was based upon a full census of the 352,000 businesses operating in Britain, the first annual Retail Inquiry of 1976 was based upon a sampling data of some 30,000 stores. Equally important, the Retail Inquiry used much higher levels of aggregation with little spatial disaggregation provided. Throughout the late 1970s and 1980s the inquiry varied from year to year in terms of both sample size and the amount of information collected As a result it has been suggested that a 'black hole' exists of 
evidence for research into the changing structure of retailing over the past thirty years (Sparks 1996).

\section{Determinants of retail productivity}

Despite concerns about the measurement of productivity, empirical studies have nevertheless identified significant determinants of the level and growth of productivity in retailing, and of international differences, e.g., as between the USA and the less productive UK (Griffith and Harmgart, 2005). Here we consider some of the determinants of productivity levels and productivity gaps, drawing on a number of comparative studies. The literature also emphasizes the role of other factors determining productivity differentials in retailing that we are omitting for ease of exposition. These are, the age of the store, as a proxy for experience and reputation (Thomas et al, 1998), and store size, as a proxy for lower unit costs of operation and management among other factors (Walters and Laffy, 1996). At this point it should be noted that, although these factors, together with the ones discussed in the rest of this section, appear to have a strong influence on the productivity performance of the retail sector overall, there is an inherent variation in the productivity performance of food and nonfood retailers. These differences originate from differences in market structures, size and trade practices of the two types of retailers and will not be discussed in this study. 


\section{Competition and the composition effect}

Changes in productivity may be due either to changes in the productivity of the incumbent firms or to a composition effect, with low productivity firms exiting the market and being replaced by new, higher productivity competitors. High entry rates may impact positively on productivity on the grounds of intensified competition, driving out poorly performing shops, and of the greater technological sophistication of new entrants.

Empirical studies show that almost all retail productivity growth in the USA in the 1990s can be accounted for by the composition effect (Foster et al. 2002). In practice, severe data limitations, mainly stemming from the level of data disaggregation (shop level) required to perform such exercises, have constrained research on the competition versus composition effect in retailing in many countries. Intriguingly, however, at the firm level, Haskel and Khawaja (2003) find that although annual entry rates in the USA are lower than in the UK, the contribution of new stores to aggregate productivity growth is higher in the USA. In practice, the entry of new establishments is associated with spatial reorganization, with the leading UK supermarkets switching investment from large edge-of-town branches, to convenience (city) stores (Griffith and Harmgart 2005), although the productivity implications of this are not fully clear. More generally, the supposed positive competition effects of high levels of new entrants are dependent on the effect of the net changes in firms on the overall level of concentration. Higher rates of exit than of entry in the UK during 1998-2000 echo the concerns of several commentators regarding reduced competition levels in retailing (Dawson 2004, Dobson and Waterson 1999, European Commission 1999, 
Competition Commission 2000), which may undermine the presumed productivity benefits of new entries.

\section{Planning Regulation}

There are two main reasons why the extent and intensity of planning regulations should be negatively related to retail productivity. First, planning regulations might result in retail stores operating below the minimum efficient scale, leading to lower productivity levels. In the case of the UK, for instance, Abramovsky et al (2006) present convinving evidence that the share of supermarket openings operating below the minimum efficiency scale ${ }^{2}$, increased substantially over the period 1991 to 2003. This increase became more pronounced after 1996, the year in which the main planning regulation, Planning Policy Guidanc 6, was introduced.

Second, planning regulations may hinder the opening of new stores or, most frequently, the closure of old ones, thereby impeding sectoral productivity gains from the substitution effect of old by newer more productive stores. Empirical research by Griffith and Hamgart (2005) on UK data suggests that planning regulations have acted as an entry barrier, although the authors also considered that the economic effects of this may have been overestimated. Flath (2003) reports similar findings: UK exhibits a lower store density than most other European cities. In particular, by measuring shop density as the number of stores per 1000 inhabitants, Flath finds it to be comparable to the one reported for the US but, since car ownership and

\footnotetext{
${ }^{2}$ According to the Competition Commission's supermarkets investigation, supermarket establishments enjoy increasing returns to scale up to a floor size of around 3,000 square metres, equivalent to 30,000 square feet.
} 
average travel distances are much higher in the US, this finding can be interpretted as conducive to UK's excessive planning regulation acting as a deterant to the opening of new retail outlets.

Moreover, the spatiality of planning regulations has been significant. In the UK, for example, whereas land-use planning in the 1980s allowed the decentralization of retailing, since the early 1990s there have been tighter restrictions on edge-of-town and greenfield development. This has contributed to a less competitive retail business environment in the UK as compared with the USA (Flath 2003) which may impact negatively on retail store productivity.

The role of information and communications technology

The relationship between labour productivity and ICT investment is expected to be Ushaped, with an initial decline in the early stages of implementation and later recovery as workers became familiar with the new equipment. Most empirical studies do confirm that in the long run there is a positive correlation between technological sophistication and retail productivity in the USA and Europe. Doms et al. (2004) show that growth in US retailing over the 1990s involved the displacement of traditional retailers by sophisticated stores, which introduced new technologies and processes. Broersma et al. (2003) demonstrate that ICT investments in the Netherlands impacted positively on productivity. Moreover, crosscountry productivity studies highlight the large post-1995 productivity gains in the USA that are attributable to increased ICT. Van Ark et al. (2003) and Basu et al. (2003) argue that the US-UK productivity differential can be partly explained by differences in ICT investment. 
More specifically, Basu et al. (2003) argue that slower TFP growth may be seen as a short run adjustment cost, stemming from the diversion of firms' available resources to reorganisation and learning. They also note that ICT prices have fallen faster in the USA than the UK, so that the UK's ICT and capital investment costs have increased more rapidly for otherwise similar kinds of investments, with a correspondingly differential effect upon productivity. ICT investments in retailing also have an immediate bearing on the relationship of the "quality of labour" to productivity, a theme that we return to later in the paper.

\section{The multinational dimension}

Retail firms have a number of motivations to internationalize, including saturation, competition and regulatory constraints in their domestic market, as well as the desire to exploit firm or ownership-specific advantages in new markets (Dicken 2003: 500). It is not surprising, then, that there has been increasing internationalization of retailing in recent years and, because of the location-bound nature of retailing (i.e. the absence of the exporting phase common in manufacturing) that this should take the form of foreign direct investment (FDI) (Palmer 2005: 23, Wrigley 2000). There was a surge of cross-border retailing mergers and acquisitions in the 1980s and 1990s (Godley and Fletcher 2001:31; Dicken 2003: 501), which Treadgold (1988: 8) claimed was "unique in its scale". The rapid growth of transnational retailing in this period is illustrated by the fact that while there were no retail firms among the world's top 100 corporations in 1993, four firms had entered this list by 1999 (Dicken 2003: 497). Wrigley and Lowe note that the "deluge" of retail FDI, especially into the emerging markets around the world, have coincided with the "rise of an embroyonic group of 
retail transnational corporations" (2007:337). At the same time that a number of retail multinationals have risen up the ranks of the largest corporations in the world, a growing number of large retailers have widened their geographical scope of activity beyond national markets. Dawson finds that, among the 100 largest retailers (ranked by size), more than half were "purely domestic" in 1986, whereas by 2004 only 29 operated solely in 1 country (2007:377). The number of firms among the largest 100 that operated in more than 20 countries went from 1 to 12 in the same time period, and the average numbers in which this group of retailers operated in from 2.8 to 10 (ibid)

Firm productivity is a significant factor in internationalization according to the theory of the multinational enterprise (Caves 1996; Dunning 2000). The theory posits that multinational enterprises (MNEs), both in whole and in part, i.e., including their foreign affiliates, are superior to purely domestic firms in their productivity. MNEs must possess some firmspecific advantage that compensate for the higher costs induced by operating in a foreign market. These compensating advantages may be in the form of superior management expertise, technological capabilities or employees' technical knowledge. Retail firms can possess specific competitive advantages based on: utilizing innovative retail formats; superior logistics and distribution systems, particularly those that reduce inventory and distribution costs; ICT systems and supply chain management; access to low-cost capital for expansion; the transfer of "best practice" knowledge; deep human capital (including management) resources. In addition, international operation confers its own advantages, e.g., access to a wide range of international management experience, and the improved ability to source supplies globally (Wrigley 2000: 306-308). Either explicitly or implicitly, 
productivity gains are based on the exploitation of the firm's organizational and knowledge advantages relative to firms operating only within domestic markets.

The superior performance of MNEs' subsidiaries compared with domestic-owned firms has been widely documented in empirical research. From a theoretical point of view, one would expect MNE to expand their operations to a new foreign market, only if they are or expect to be on average more productive than strictly-domestic competitors. Thus the entrance of new, more productive, firms leads to an economy-wide, productivity-boosting process, during which domestic inefficient firms are replaced by more efficient rivals, a process often cited in the economics literature as 'creative destruction' (Schumpeter, 1976). For the UK, Griffith et al. (2004) found that foreign-owned affiliates are, on average, 25 per cent more productive in terms of value added per worker than locally-owned non-multinational firms, and are also more productive than British-based MNEs in both the manufacturing and service sectors. Criscuolo and Martin (2005) show that foreign-owned MNEs in the UK are roughly twice as productive (output per worker) as domestic firms. They also found evidence that UK MNEs are less productive than US owned affiliates, but as productive as other foreign owned affiliates. However, care is required in generalizing from aggregate level studies, or manufacturing specific studies, to retailing, as the multinationality effect may be highly sector specific, and dependent on competitive practices within the sector (for example, Tüselmann, McDonald and Heise 2003).

The role of knowledge is explicitly acknowledged as a determinant of firm internationalisation, and therefore of multinational activity. It follows that knowledge may be 
a key determinant of productivity differences between firms and of productivity levels within firms, and this is now considered in the following section.

\section{Inter- and intra-firm knowledge transfers and retail productivity}

The analysis discussed above recognizes the role of knowledge only in the residual TFP element in the measurement of productivity. In other words, knowledge is captured (together with many other elements) in the 'other' category and used for conclusions not readily explained by other factors. The specialist knowledge management (KM) literature, to which we now turn, puts knowledge in centre stage instead. Most research in retailing has focused on technology, specifically on ICT, as the main means for knowledge transfer and innovation.

The relationship between knowledge and productivity in retailing is mediated by several distinctive features. In common with many service sector industries, formal R\&D is less central to knowledge creation, and there is more emphasis on the knowledge possessed by customers, and knowledge transfers from suppliers. Den Hertog's (2002) four-dimensional model of service innovation highlights four areas of knowledge creation and transfer in retailing (Wrigley et al. 2005): new service concepts (e.g. new store formats), new client interfaces (e.g. online shopping), new service delivery systems (e.g. home delivery) and technological options (e.g. client profiling and data mining). These can all contribute to the productivity of individual firms, but two significant challenges face retail firms in utilizing knowledge: the protection of proprietary knowledge, and the significance of knowledge of 
localized consumer markets.

First, in terms of proprietary knowledge, many areas of product innovation are highly visible to competitors and are difficult to protect (Currah and Wrigley 2004: 9). Therefore, backstage process-based knowledge (for example, the application of ICT systems to data mining) is particularly important to competitive advantage, and productivity enhancement. Second, firms need knowledge of distinctive multiple markets (Currah and Wrigley 2004: 6). Traditionally this was seen as stressing localized tacit knowledge and the need for central management to find ways to harvest and redistribute this within the company. However, recent changes in technology (such as the data provided by loyalty cards) have allowed significant codification of such knowledge, giving the centre greater access to some forms of localized knowledge.

In addition to these distinctive challenges of knowledge utilisation and protection, retailing firms also face generic challenges confronted by all firms in knowledge transfer and management, as discussed below in relation to tacit versus codified knowledge, and to interand intra-firm knowledge transfers.

\section{Tacit versus codified knowledge}

The classic division between tacit and codified knowledge dates from Polanyi (1966). Most research on productivity has centred on codified knowledge, since this is more easily observed and quantified. In retailing, research on codified knowledge has mostly focused on the relationships between ICT and company performance. Currah and Wrigley (2004: 130) 
report on the use of in-house intranets to generate and distribute target benchmarks and performance ratings amongst the branches of multi-establishment retail companies. ICT also facilitates the analysis of large volumes of data from retailers' own sales information and loyalty card programs, as well as secondary data and specially commissioned surveys. This leads to greater centralization and, to some extent, to the codification of what had previously been tacit knowledge about local markets (Wood 2000). For example, US electronics retailer Best Buy evolved a 'customer centricity' model, whereby individual stores target highly segmented localized markets, based on such explicit 'local' knowledge (Financial Times 31 October 2005).

Tacit knowledge is held to be easier to protect than codified knowledge and this therefore also applies to the resulting enhancement of productivity in individual firms. There are many different forms of tacit knowledge (Blackler 2002) and this is articulated in complex ways within companies (Cavusgil et al. 2000). At the individual level it can be found in particular skills as well as within forms of abstract knowledge, whilst collective tacit knowledge 'typically resides in top management' (ibid. page 9). The obstacles to knowledge transfers within companies, especially given the dispersed nature of knowledge within organizations, can be formidable (for example Foss and Pedersen 2002).

The key question for firms is not whether to focus on tacit knowledge or codified knowledge, but how to combine these most effectively in order to enhance productivity, as illustrated by the high levels of ICT in retailing (Oulton and Srinivasan 2005). Investment in ICT is claimed to contribute to timeliness, quality, variety and customization (Brynjolfsson and 
Yang 1996) but there are significant differences in investment in ICT between types of firms. Multinationals have higher levels of investment in information technology than domestic companies, whilst US-owned establishments have significant advantages over all other MNEs in this respect (Bloom et al. 2007).

\section{Inter-versus intra-firm knowledge transfers}

The choice of transferring knowledge within rather than between firms is known as the 'internalization' decision, and is addressed by the transactions cost literature (Coase 1937; Williamson 1985; Buckley and Casson 1976). Barriers to knowledge transfer (discussed later in relation to 'absorptive capacity') create transaction costs and firms assess whether these are greater in external markets (inter-firm transfer) than in internal markets (intra-firm transfer). This influences their knowledge transfer strategies, as well as decisions about mergers, acquisitions and collabouration. However, the decision as to whether to acquire knowledge internally or externally is also influenced by non-economic costs related to interpersonal relationships and trust. Insiders may be preferred sources of knowledge for reasons associated with social identities or ease of access, while outsiders may be preferred because external knowledge is more highly valued for status and scarcity reasons (Menon and Pfeffer 2003: 497). Of course, these are not discrete options and, as Currah and Wrigley (2004: 2) argue, the key to retail firm performance is 'the interplay between extra-firm (or firm-place) networks of store-based learning and intra-firm networks of knowledge exchange and organizational adaptation'. In the following two sections, we consider inter- and intra-firm knowledge transfers in more detail. 
Inter-firm knowledge transfer

With respect to inter-firm knowledge transfers, firms may acquire codified knowledge from other firms via trade, e.g., the purchase of computer software, and this is particularly important in the service sector. Tacit knowledge is more likely to flow within 'learning networks' of people (Tempest 1999) that may operate both within and across the boundary of the firm. This social constructionist view redraws the map of the firm's knowledge creation and transfer activities (Davenport et al. 1998; Ruggles 1998). Four main milieux have been recognized as important in facilitiating tacit knowledge flows amongst firms:

- Communities of practice (Wenger 1998) are informal professional networks where individuals are bound together by shared understandings. They transcend the boundaries of firms and localities, and are based on trust and shared understanding that are enhanced by, but do not rely on, face to face contact.

- Geographical clusters, conceptualized as learning regions, have high rates of innovation and creativity due to localized tacit knowledge spillovers, facilitated by shared values and trust, generated through formal and informal local networks (Maskell and Malmberg 1999). Clusters are not enclaves, isolated from external inflows of knowledge, because the latter are also critical to innovation (Bathelt et al. 2004) and productivity, whether through electronic communication or human mobility. This is also a feature of 'knowledge communities' (see, for example, Henry and Pinch 2000) where knowledge transfers are based on rapid staff turnover, 
alongside cross-cutting supply networks, rapid births and deaths of firms, and being tuned in to localized gossip and shared discourses.

- Labour mobility is an important source of knowledge spillovers (Arrow 1962), irrespective of whether clusters are involved. For example, Almeida and Kogut (1999) have demonstrated how the mobility of key engineers spread ideas in the semi-conductor industry.

- Knowledge brokers. Wenger (2000) identified several types of brokers, those individuals who play a key role in mediating knowledge transfers, including 'boundary spanners' (Tushman and Scanlan, 1981), 'roamers', and 'outposts'. Although research on this topic in retailing has been limited, Shaw and Alexander (2006) have demonstrated that individuals who held inter-locking company directorships played a key role in knowledge transfers amongst supermarkets in the 1950s.

Currah and Wrigley (2004) are among a number of writers who emphasize the importance, in relation to international competitiveness, of extra- and intra-firm 'relational networks' for knowledge transfer in retail MNEs. Alexander et al. (2005) found that the main sources of knowledge transfer in supermarkets in the 1950s were the trade press, government reports, learning from interactions especially from equipment suppliers, key individual knowledge brokers, and an influential community of practice, based around the Self Service Development Association. Both tacit and codified knowledge were important in transfers 
between firms, as were different milieux, and this is consistent with our earlier discussion of different types of tacit knowledge. The importance of localised knowledge in retailing points to the potential importance of geographical clusters, while human mobility (labour turnover, migration etc) is also key to effecting transfers of tacit knowledge.

The literature on intra-firm transfers argues that firms are distributed knowledge systems, composed of knowledge embodied in individual employees and their social interactions (Tsoukas 1996; Un and Cuervo-Cazura 2004). Firms may adopt top-down organizational strategies to capture and redistribute such knowledge (Brown and Eisenhardt 1997). However, many knowledge transactions are informal, involving face to face contacts between pairs or small groups of workers. Firms may seek to enhance these through promoting a corporate culture which stresses openness and co-operation. But even where companies capture such knowledge, effective redistribution can be problematic in retailing. As Currah and Wrigley (2004: 11) argue, given the importance of store based learning (or local knowledge), the extent to which best practices within multinational retail companies can be successfully adopted outside their original socio-cultural context is uncertain.

\section{Knowledge and human resource management}

The view that firms are distributed knowledge systems (Tsoukas, 1996), where knowledge is embodied in their employees, implies that a process of knowledge transfer arises whenever there are interactions among employees. Knowledge creation is a more complex process since knowledge transfer among workers with different (but somewhat overlapping) 
knowledge sets, operating in different parts of the firm and sharing a common language is needed for an innovation to be realised (Un and Cuervo-Cazurra, 2004). Not surprisingly, therefore, human resource management plays a key role in knowledge management, and a number of studies suggest a positive relationship between selective human resource (HR) practices and organisational performance in the USA (Appelbaum et al. 2000; Ichniowski et al. 1997; Cappelli and Neumark, 2001; though see also Guest etl al., 2003).

The key argument is that employees may possess valuable knowledge on products and/or processes that managers may lack. Eliciting discretionary effort from employees in order for them to use this knowledge to improve organisational performance (through productivity or quality improvements) can be accomplished by realising three conditions (Appelbaum et al. 2000): enhancing workers' ability, motivation and opportunity to participate in the decisionmaking process of the organisation. Workers' ability, ensured through the selection and initial training of employees with high skills or formal education, allows the deployment of a large stock of human capital and its further deepening through learning. Workers' motivation, like their commitment and attachment to the workplace, is reached through the provision of incentives such as investments in further training, employment security, and trust-enhancing systems of performance management like performance-related pay and internal promotions. Finally, the existence of self-managed teams and other problem-solving groups can provide workers with the discretion and opportunity to use their knowledge collaboratively.

Research on the link between HRM practices and ICT is particularly important for retailing. 
Shaw (2003) and Black and Lynch (2001) suggest that ICT and HRM practices are complementary and that appropriate HRM may significantly increase the returns to ICT. A large part of the productivity differential between the USA and UK has been related to differences in ICT usage, and since the retail sector is among the largest contributors to the UK's ICT capital deepening, it is possible that effective use of ICT in retailing accounts for a significant part of observed international productivity gaps (Griffith and Harmgart, 2005).

There still needs to be further research on most aspects of the relationship between HRM practices and firm performance for the service sector in general (but see Delery and Doty 1996, Bartel 2004, Batt 2002, and Boxall 2003). For retailing, empirical evidence on the relationship between HR practices and productivity is provided by Jones et al. (2006). In a case study of 34 establishments belonging to a Finnish non-food retail firm, the authors found a positive association between HR practices and productivity in a setting where employees were unskilled and carried out simple tasks. There has also been a debate as to whether HRM practices should have a greater impact on productivity in manufacturing but this has largely been inconclusive. On the one hand, Ber-Ner et al. (1999) argue that the payoff to HRM practices is greater in manufacturing, due to higher uncertainty, interdependence and complexity of tasks compared to the service sector. But the importance of managing customer contacts (Mills, Chase and Margulies, 1983) suggests that the service sector is more likely to benefit from HRM (Bartel, 2004, Banker et al. 1996). Pertinently, Peccei and Rosenthal (2001) provide retail store-based (supermarket) evidence that HR practices empowering employees have a positive effect on their customer-oriented behaviour, which could affect productivity measurements based on sales. 
There is also the view that the nature of the customer market segment moderates the HRperformance relationship, and Batt (2002) illustrates this with respect to call centres. HR practices are more effective in enhancing sales growth if the services are directed towards low-value-added customers (residential and small business) rather than high-value-added ones (large businesses). This is because they are characterised by high-volume and low-cost transactions, but they leave room for service customisation (hence, HR practices are valuable). Another view is that HR only offers competitive advantage to professional service firms that extensively deploy intangible capital, that is, to knowledge-intensive firms (Swart and Kinnie 2003). However, this view is simplistic, and Boxall (2003) stresses that in order to fully understand the advantage of HR practices in the service sector, it is also necessary to consider the firm's business strategy, as well as its customer segments. But these links, and the relationship between motivation and performance are neither simple nor uncontested. Indeed, in Sutton and Rafaeli's (1988) study of convenience stores, good customer service actually had a negative effect on performance.

\section{Skills and productivity in retailing}

The final section of our review underscores the importance of the relationship between skills and firm performance. Regrettably, the knowledge management literature conflates "knowledge" in the systems and processes of firms (see, for example Leadbeater 2001, Scarbrough and Swan 2001) with knowledge possessed by workers (Nonaka and Takeuchi 1995, Karreman and Alvesson 2004). This is a serious confusion which obscures (among other things) the nature of knowledge work, the form taken by the labour market, and the 
type of labour force currently demanded by employers. Both knowledge in processes and knowledge in people may add to firm productivity and competitiveness but one does not necessarily involve the other. Indeed, detailing organisational procedures can and does actively deskill work (Davenport and Klahr 1998), while research into the elite of knowledge workers reveals unusual, light touch or widely flouted control mechanisms (Alvesson and Sveningsson 2003, McKinlay 2000, Randle and Rainnie 1997, Robertson, Scarbrough and Swan 2003).

Here we focus on what is known about the agency and quality of the people involved in retail, which are major factors in the production and service provision processes. As noted earlier, the intangible nature of the output, the relationships between customers and employees, and different scopes for protecting knowledge in front and back region operations makes it particularly important to study skills in retailing (Goldman 2001). The quality and skills repertoire of the workforce of a retailer is informed by local labour market conditions, and also by the management of labour within the confines of the organisation. Empirical studies suggest that international skills differences are a likely contributor to differences in productivity levels between countries, particularly with respect to advanced countries such as France and Germany (Broadberry and O'Mahony 2004).

International differences in the skill demands on retail workers can be particularly revealing. In France both retailers and customers expect high levels of technical and product knowledge from salespeople (McGauran 2000) while in Germany rigorous three-year apprenticeships mean that workers are skilled in most aspects of store work and may be flexibly deployed. In 
Britain, by contrast, retail hiring practices can be dominated by judgements about the applicant's availability for work, proximity to the workplace and gender, something which later feeds in to the way that labour is used and controlled. In the UK, retail work is dominated by longer opening hours and the pursuit of "hyperflexibility", leading to what has been described as "tantamount to a personnel strategy based on zero competence", zero qualifications, zero training and zero career (Gadrey 2000:26). At the same time, some types of retailing may require detailed technical and specialist knowledge (Darr 2004) and individual retailers may design work so that employees are experts in the products they sell (Gadrey et al. 2001).

The changing structure of retailing towards a computerized, technologically sophisticated sector has contributed to increasing interest in retailing as a driver of productivity growth. The increased use of ICT is also contributing to changes in skills in retailing. This may "professionalise" retail work but it may also deskill as central direction on store design, work schedules etc. replaces local autonomy (Sparks 2000a, 2000b, Akehurst and Alexander 1996, Broadbridge 2002). Computers are popularly associated with rising skill levels and there is an identifiable wage premium available for individuals working with them (Haskel 1999, Haskel and Heden 1999, Krueger 1993), perhaps because introducing technology changes the way people work. However, technology does not automatically upskill workers. Starting from the late 1980s and early 1990s, working with PCs and other basic ICT on the job ceased to be a mark of either skill or status. It may be, as Machin (2001) suggests, that computers are now so widespread in the workplace that simply counting them is not a meaningful measure of skill, particularly since not all computer use is complex (Tijdens and Steijn 2005). 
In practice, empirical evidence suggests that technology impacts differently on different groups of workers, even in the same retail field, firm, or even the same workplace. Wong and Hendry (1999:475-76) identify four major groups of employees in the retail firm: store managers, employees working in inventory and buying, employees who handle retail sales technology itself, and sales staff. They concluded that, while store managers and sales staff were deskilled through the implementation of electronic sales technology, the other groups of employees may have become more knowledge-able.

Another fundamental feature of employment in the retail workplace is the employers' extensive reliance on more than the technical skills of employees. The issue of "quality labour" is not a straightforward one since what employers are harnessing is not the mechanistic aggregation of an individual worker's skills and abilities but their capacity to do work (Block 1990). Such a capacity is reciprocal and relational, particularly when considering the soft, social and customer facing skills most in demand by retailers. As Lafer (2004:117 - 118) points out: "traits such as discipline, loyalty and punctuality are not "skills" that one either possesses or lacks; they are measures of commitment that one chooses to give or withhold based on the conditions of work offered."

Finally, a significant component of the management of labour in retailing pertains to the management of working time. Despite the focus on customer service, knowledge and commitment, generally associated with full-time, stable employment, more than half of retail employment in some countries is part-time, and is characterised by considerable flexibility 
(Burt and Sparks 2003, Arrowsmith and Sisson 1999). Some stores deploy sophisticated HR management techniques (as mentioned above) but these are set against generally low wage rates, rigid control mechanisms and limited discretion (Arrowsmith and Sisson 1999, Broadbridge 2002, Burt and Sparks 2003). The relative proportions of full time versus parttime or casual workers also differ significantly across countries (Reynolds et al. 2005), with the USA and France, for instance employing a higher proportion of full-time workers than the UK.

Disentangling these very different ways of organising labour and developing or restricting skills from productivity and performance is difficult. As noted above, in the service sector, improvements to service (such as opening an additional till to reduce a queue) equal reductions in labour productivity. In manufacturing, such improvements to product specification might be observed separately (Keep and Mayhew, 1999), in services much of the data conflates staffing inefficiencies with improvements to the service supplied in ways that are difficult to separate with quantitative data. Further, while some sources do argue, as discussed above, that HR practices can impact on motivation which may affect service levels the link is a contested one and simple behavioural modification by staff may have exactly the same impact (Rosenthal et al., 1997). Linking qualitative data to quantitative assessments of productivity can help to clarify this and also offers a wider range of criteria against which performance can be gauged. 


\section{Conclusion}

This review has analysed the factors generating productivity outcomes and the specific processes that the literature has identified as critical for bringing about these outcomes. As such, it provides the basis for a framework within which future research agendas can be formulated.

We can identify three key areas in which future research would be particularly instructive. First, there are measurement issues as they relate to the assessment of productivity adopting econometric analysis methods. There are particular complications in the measurement of retail outputs and inputs which require further attention. We argue that econometric analysis of retail productivity can be enhanced by focusing on total factor productivity, which has five major determinants: competition and composition effects, planning regulations, information and communication technologies, the composition of employment and the role of skills, and the multinational dimension. These were discussed at various points in the paper, and in relation to different contributory streams of research on retail productivity.

Second, while we have considered the framework for a multi-faceted approach to the capture of productivity levels in quantitative outcomes, we have also suggested that three key areas merit particular attention. The role of multinational activities, linked to comparative advantages in terms of costs and knowledge, requires more detailed research: there is a need to consider not only the differences between domestic and foreign owned firms, but also between those nationally owned firms which have only domestic activities, and those which 
also have international activities. This is given additional urgency because until recently, levels of internationalisation were relatively low in retailing, compared with other sectors. We also contend that tacit knowledge, as well as codified knowledge (epitomised by ICT investments) and inter- and intra-firm knowledge transfers should be a major topic of investigation in retail productivity research. Additionally, the analysis of the role of skills in defining productivity outcomes, frequently cited in aggregate econometric analyses, should be deepened to problematise how the knowledge embodied in the retailing workforce is defined, distributed, and experienced in real workplaces.

Finally, while emphasising the limitations of econometric studies based on secondary data sources, we are not arguing for these to be abandoned. Rather, we believe there is the need for more multi-layered approaches, which are multi-scalar (looking at the sector, firms and establishments), and multi-method, combining quantitative and qualitative approaches and extending into international comparative research. Such research faces considerable theoretical and methodological challenges, but does offer an opportunity to combine the rigour and generalization associated with quantitative approaches, with the perspectives offered by qualitative approaches on knowledge and skills within different types of firms. 


\section{References}

Abramovsky L., Bond S., , Harrison R. and H. Simpson (2005), Productivity Policy, IFS

Briefing Note no. 60.

Akehurst, G., and Alexander, N. (eds.) (1995). Retail Employment. London: Frank Cass.

Alexander, A., Shaw, G., and Curthe, L. (2005). Promoting retail innovation: knowledge flows during the emergence of self- service and supermarket retailing in Britain.

Environment and Planning A, 37, 805-821.

Almeida, P. and Kogut, B. (1999). Localization of knowledge and the mobility of engineers in regional networks. Management Science, 45, 905-917.

Alvesson, M., and Sveningsson, S. (2003). Good visions, bad micro-management and ugly ambiguity: contradictions of (non-)leadership in a knowledge-intensive organization. Organization Studies, 24 961-988.

Aoyama, Y. (2007) Oligopoly and the structural paradox of retail TNCs: an assessment of Carrefour and Wal-Mart in Japan, Journal of Economic Geography, 7, 471 - 490

Appelbaum, E., Bailey, T., Berg, P., and Kalleberg, A. (2000). Manufacturing Advantage: Why High-Performance Systems Pay Off. Ithaca, NY: ILR Press.

Arrow, K. J. (1962). Economic welfare and the allocation of resources for invention. In Nelson, R. R. (ed.), The Rate and Direction of Inventive Activity: Economic and Social Factors. National Bureau of Economic research (NBER) Special Conference Series. Princeton, NJ: Princeton University Press, NBER Special Conference Series.

Arrowsmith, J. and Sisson, K. (1999). Pay and working time: towards organisation-based Systems? British Journal of Industrial Relations, 37, 51 - 75.

Banker, R. D. Lee, S.-Y., Potter, G. and Srinivasan, D. (1996). Contextual analysis of performance impacts of outcome-based incentive compensation. Academy of Management Journal. 39, 920-948.

Bartel, A. P. (2004). Human resource management and organizational performance: evidence from retail banking. Industrial and Labour Relations Review. 57, 181-203.

Basu, S., J. Fernald, N. Oulton and S. Srinivasan (2003). The Case of Missing Productivity Growth: or, Does Information Technology Explain Why Productivity Accelerated in the United States but not in the United Kingdom?. Cambridge, Massachusetts: NBER, Working Paper No. 10010. National Bureau of Economic Research, Inc.

Bathelt, H., Malmberg, A. and Maskell, P. (2004). Clusters and knowledge: local buzz, global pipelines and the process of knowledge creation, Progress in Human Geography 
28, 31-56.

Batt, R. (2002). Managing customer services: human resource practices, quit rates, and sales growth. Academy of Management Journal. 45, 587-597.

Ber-Ner, A., Kong, F. and Bosley, S. (1999). Workplace Organization and Human Resource Practices: The Retail Food Industry, Minnesota: University of Minnesota, The Retail Food Industry Center, WP 00-01.

Betancourt, R. (2004). The Economics of Retailing and Distribution. London: Edward Elgar Publishing, Ltd.

Black, S. E. and Lynch, L. M. (2001). How to compete: the impact of workplace practices and information technology on productivity. Review of Economics and Statistics, 83, 434445 .

Blackler, F. (2002). Knowledge, knowledge work and organizations. In Choo, C. W. and Bontis, N. (eds). The Strategic Management of Intellectual Capital and Organizational Knowledge. New York: Oxford University Press.

Block, F. (1990). Postindustrial Possibilities: A Critique of Economic Discourse. Berkeley: University of California Press.

Bloom N., Sadun, R. and Van Reenen, J. (2007) Americans Do I.T. Better: US Multinationals and the Productivity Miracle, Cambridge, Massachusetts: NBER Working Paper No. 13085. National Bureau of Economic Research, Inc.

Borin, N. and Farris, P. (1990). An empirical comparison of direct product profit and existing measures of SKU productivity. Journal of Retailing, 66, 297-314.

Boxall, P. (2003). HR strategy and competitive advantage in the service sector. Human Resource Management Journal, 13, 5-20.

Broadberry, S., O'Mahony, M. (2004). Britain's productivity gap with the United States and Europe: a historical perspective. National Institute Economic Review. 189, 72-85.

Broadbridge, A. (2002). Rationalising retail employment: a view from the outside looking in. International Journal of Retail and Distribution Management. 30, 536 - 543.

Broersma, L., McGuckin, R.H, and Timmer, M.P. (2003). The impact of computers on productivity in the trade sector: explorations with Dutch microdata. De Economist. 151, 53-79.

Brown, S. L., and Eisenhardt, K.M. (1997). The art of continuous change: Linking complexity theory and timepaced evolution in relentlessly shifting organizations. Administrative Science Quarterly. 42, 1-34. 
Brynjolfsson, E., and Yang, S. (1996). Information technology and productivity: a review of the literature. Advances in Computers. 43, 179-214.

Buckley, P.J. and Casson, M.C. (1976). The Future of the Multinational Enterprise. London: Macmillan.

Burt, S., and Sparks, L. (2003). Competitive Analysis of the Retail Sector in the UK. London: Department of Trade and Industry.

Cappelli, P. and Neumark, D. (2001). Do 'high-performance' work practices improve establishment-level outcomes? Industrial and Labour Relations Review. 54, 737-775.

Caves, R. (1996). Multinational Enterprise and Economic Analysis, (second Edn.). Cambridge: Cambridge Surveys of Economic Literature, Cambridge University Press.

Cavusgil, S. T., Calantone, R. J. and Zhao, Y. (2003). Tacit knowledge transfer and firm innovation capability. Journal of Business and Industrial Marketing, 18, 6-21.

Christopherson, S. (2007) Barriers to 'US style' lean retailing: the case of Wal-Mart's failure in Germany, Journal of Economic Geography, 7, 451-469.

Coase, R.H. (1937). The nature of the firm. Economica. 4, 386-405.

Coe, N. And Wrigley, N. (2007) Host economy impacts of transnational retail: the research agenda. Journal of Economic Geography, 7, 341-371.

Cox, R. (1948). The meaning and measurement of productivity in distribution. Journal of Marketing, 12, 433-441.

Competition Commission (2000). Supermarkets: A Report on the Supply of Groceries from Multiple Stores in the United Kingdom. London: Competition Commission, Report Cm4842.

Criscuolo, C., and Martin, R. (2003). TFP Growth in British and German Manufacturing, 1950-1996. Centre for Economic Policy Research, Discussion Paper No. 3078.

Currah, A. and Wrigley, N. (2004). Networks of organizational learning and adaptation in retail TNCs. Global Networks, 4, 1-24.

Darr, A. (2004). The interdependence of social and technical skills in the sale of emergent technology. In Warhurst, C. Grugulis, I. and Keep, E. (eds.) The Skills that Matter. Basingstoke: Palgrave Macmillan.

Davenport, T. H., De Long, D. W. and Beers, M. C. (1998). Successful knowledge management projects. Sloan Management Review, 39, 43-57. 
Dawson, J.A. (2007) Scoping and conceptualising retailer internationalisation. Journal of Economic Geography, 7, 373-397.

Dawson, J. A. (2004). Retail Change in Britain During 30 Years: the Strategic Use of Economies of Scale and Scope, Working Paper, Centre for the Study of Retailing in Scotland (available at www.csrs.ac.uk).

Delery, J. E. and Doty, D. H. (1996). Modes of theorizing in strategic human resources management: tests of universalistic, contingency, and configurational performance predictions. Academy of Management Journal, 39, 802-835.

den Hertog, P.D. (2002). Co-producers of innovation: on the role of knowledge-intensive business services in innovation. In Gadrey, J. and Gallouj, F. (eds.), Productivity, Innovation and Knowledge in Services. Cheltenham: Edward Elgar.

Dicken, P. (2003). Global Shift: Reshaping the Global Economic Map in the 21st Century. London: Sage Publications.

Dobson, P.W. and M. Waterson (1999). Retailer power: recent developments and policy implications. Economic Policy, 14, 135-164.

Doms, M., R. Jarmin and S. Klimek (2004). Information technology investment and firm performance in US retail trade. Economics of Innovation and New Technolog., 13, 595613.

DTI (Department of Trade and Industry) (2004). Driving Change: The Retail Strategy Group Report. London: DTI.

Dunning, J.H. (2000). The eclectic paradigm as an envelope for economic and business theories of MNE activity. International Business Review, 9, 163-190.

ESRC (2004). The UK's Productivity Gap: What Research Tells Us and What we N to Find Out. Swindon: Economic and Social Research Council Seminar Series.

European Commission (1999). Buying Power and its Impact on Competition in the Food Retail Distribution Sector of the European Union. Report produced for the European Commission, DG IV, Brussels.

Financial Times (2005). Divide and conquer: Best Buy's strategy. Financial Times 31st October, p10

Flath, D. (2003). Regulation, Distribution Efficiency, and Retail Density. Cambridge, Massachusetts: NBER Working Paper No. 9450, National Bureau of Economic Research, Inc. 
Foss, N. J. and Pedersen, T. (2002). Transferring knowledge in MNCs: the role of sources of subsidiary knowledge and organizational context. International Management, 8, 49-67.

Foster, L., J. Haltiwanger and C.J. Krizan (2002). TheLink Between Aggregate and Micro Productivity Growth: Evidence from Retail Trade. Cambridge, Massachusetts: NBER Working Paper No. 9120, National Bureau of Economic Research, Inc.

Gadrey, J. (2000). Working time configurations: theory, methods and assumptions for an international comparison. In Baret, C., Lehndorff, S. and Sparks, L. (eds.) Flexible Working in Food Retailing: a Comparison Between France, Germany, the UK and Japan. Routledge: London.

Gadrey, J., Jany-Catrice, F. and Ribault, T. (2001). Levels and systems of employment in the Japanese retail trade: a comparison with France. Cambridge Journal of Economics, 25, $165-184$

Godley, A., and Fletcher, S.R. (2001). International retailing in Britain, 1850-1994. The Service Industries Journal, 21, 31-46.

Goldman, A. (2001). The transfer of retail formats into developing economies: the example of China., Journal of Retailing, 77, 221-242.

Goodman, C.S. (1985). On output measures of retail performance. Journal of Retailing, 60 $77-82$.

Grabher, G. (2001). Ecologies of creativity: the village, the group, and the heterarchic organisation of the British advertising industry. Environment and Planning A 33, 351374.

Griffith, R. and Harmgart, H. (2005). Retail productivity. International Review of Retail, Distribution and Consumer Research, 15, 281-290.

Griffith, R., Harrison, R., Haskel, J. and Sako, M. (2003). The UK Productivity Gap and the Importance of the Service Sector. AIM Briefing Note. Available at http://www.aimresearch.org/publications/rgbrief.pdf

Griffith, R. Redding S., and Simpson, H. (2004). Foreign ownership and productivity: new evidence from the service sector and the R\&D lab, Oxford Review of Economic Policy, $20,440-456$.

Guest, D., J. Michie, N. Conway, and M. Sheehan. (2003). Human Resource Management and Corporate Performance in the UK. British Journal of Industrial Relations 41,291-314

Haskel, J. (1999). Small firms, contracting out, computers and wage inequality: evidence from UK manufacturing. Economica, 66, 1-21. 
Haskel, J.and Y. Heden. (1999). Computers and the demand for skilled labour: industry and establishment level panel evidence for the UK. The Economic Journal, 109, 68-79.

Haskel, J. and Khawaja, N. (2003). Productivity in UK Retailing: Evidence from Micro Data, London: CeRiBA. Working Paper.

Hean, H., Keh, T., and Chu, S. (2003). Retail productivity and scale economies at the firm level: a DEA approach. Omega: International Journal for Management Science, 31, 7582.

Henry, N. and Pinch, S. (2000). Spatialising knowledge: placing the knowledge community of motor sport valley. Geoforum, 31, 191-208.

Ichniowski, C., Shaw, K. and Prennushi, G. (1997). The Effects of Human Resource Management Practices on Productivity: A Study of Steel Finishing Lines. American Economic Review. 87, 291-313.

Jones, D. C., Kalmi, P., and Kauhanen, A. (2006). Human resource management policies and productivity: new evidence from an econometric case study. Oxford Review of Economic Policy. 22, 526-538.

Kamakura, W., Lenartowicz, T. and Ratchford, B. (1996). Productivity assessment of multiple retail outlets. Journal of Retailing.; 72, 333-356.

Karreman, D.and M. Alvesson. (2004). Cages in tandem: management control, social identity and identification in a knowledge-intensive firm. Organization, 11, 149 - 175.

Krueger, A. (1993). How computers have changed the wage structure: evidence from microdata 1984 - 1989. Quarterly Journal of Economics, 108, 33 - 60.

Lafer, G. (2004). What is skill?. nI Warhurst, C., Grugulis, I. And Keep, E. (eds.), The Skills that Matter. Basingstoke: Palgrave Macmillan.

Leadbeater, C. (2001). How should knowledge be owned?. In Nonaka, I. And Teece, D. (eds.), Managing Industrial Knowledge. London: Sage.

Machin, S. (2001). The changing nature of labour demand in the new economy and skillbiased technology change. Oxford Bulletin of Economics and Statistics, 63, 753 - 776.

Maskell, P. and Malmberg, A. (1999). Localised learning and industrial competitiveness. Cambridge Journal of Economics, 23, 167-185.

McGauran, A-M. (2000). Vive la différence: the gendering of occupational structures in a case study of Irish and French retailing. Women's Studies International Forum, 23, 613 627. 
McGoldrick, P. (2002). Retail Marketing. Maidenhead: McGraw-Hill Education.

McKinlay, A. (2000). The bearable lightness of control: organisational reflexivity and the politics of knowledge management," In Prichard, C., Hull, R., Chumer, M. And Willmott, H. (eds.), Managing Knowledge: Critical Investigations of Work and Learning. Basingstoke: Macmillan.

McKinsey Global Institute (1998). Driving Productivity and Growth in the UK Economy. McKinsey.

Menon, T. and Pfeffer, J. (2003). Valuding internal vs external knowledge: explaining the preference for outsiders. Management Science, 49, 497-513.

Mills, P. K., Chase, R. B., and Margulies, N. (1983). Motivating the client/employee system as a service production strategy. Academy of Management Review, 8, 301-310.

Nadiri, M I. (1970). Some approaches to the theory and measurement of total factor productivity: a survey. Journal of Economic Literature, American Economic Association, 8, 1137-1177.

Nakamura, L.I. (1999). The measurement of retail output and the retail revolution. Canadian Journal of Economics, 32,.408-425.

Nohria, N. and Ghoshal, S. (1997). The Differentiated Network. San Francisco: Jossey-Bass.

Nonaka, I. and H. Takeuchi. (1995). The Knowledge Creating Company: How Japanese Companies Create the Dynamics of Innovation. New York: Oxford University Press.

O'Mahony, M. and de Boer, W. (2002).. Britain's relative productivity performance: updates to 1999, London: National Institute of Economic and Social Research (NIESR).

Oulton, N. and Srinivasan, S. (2005). Productivity Growth in UK Industries, 1970-2000: Structural Change and the Role of ICT. London: Bank of England, Working Paper No. 259.

Palmer, M. (2005) Crossing threshold periods in the retail firm's life cycle: insights from Wal-Mart International. European Management Journal, 23(6),717- 729.

Peccei, R. and Rosenthal, P. (2001). Delivering customer-oriented behaviour through empowerment: an empirical test of HRM assumptions. Journal of Management Studies, 38, 831-857.

Polanyi, M. (1966). The Tacit Dimension. London: Routledge \& Kegan Paul.

Randle, K. And Rainnie, A. (1997). Managing creativity, maintaining control: a study in pharmaceutical research. Human Resource Management Journal 7, 32 - 46. 
Reardon, J. and Vida, I. (1998). Measuring retail productivity: monetary vs. physical input measures. International Review of Retail, Distribution and Consumer Research, 8, 399413.

Reynolds, J., Howard, E., Dragun, D., Rosewell, B. and Ormerod, P. (2005). Assessing the productivity of the retail sector. International Review of Retail, Distribution and Consumer Research, 15, 237-280.

Robertson, M., Scarbrough, H. and Swan, J. (2003). Knowledge creation in professional service firms: institutional effects. Organization Studies, 24, 831-857.

Ruggles, R., (1998). The state of the notion: knowledge management in practice'. California Management Review, 40, 80-89.

Scarbrough, H. and Swan, J. (2001). Explaining the diffusion of knowledge management: the role of fashion. British Journal of Management 12, 3 - 12.

Schumpeter, Joseph A, 1976, Capitalism Socialism, and Democracy (Harper \& Row, New York).

Shaw, K. (2003). The human resources $r$ : is it a productivity driver?. In Jaffe, A., Lerner, J. and Stern, S. (eds.), Innovation, Policy and the Economy, Chicago: University of Chicago, National Bureau of Economic Research.

Shaw, G. and Alexander, A. (2006). Interlocking directorates and the knowledge transfer of supermarket retail techniques from North America to Britain. International Review of Retail Distribution and Consumer Research, 16, 375-394.

Solow, R. M. (1956). A contribution to the theory of economic growth.Quarterly Journal of Economics, 70, 65-94.

Sparks, L. (2000a). The rise of the large format food store. In Baret, C., Lehndorff, S. and Sparks, L. (eds.), Flexible Working in Food Retailing: A Comparison Between France, Germany, the UK and Japan. London: Routledge.

Sparks, L. (2000b). Employment in food retailing. In Baret, C., Lehndorff, S. and Sparks, L. (eds.), Flexible Working in Food Retailing: A Comparison Between France, Germany, the UK and Japan. London: Routledge.

Sparks L., (1996). The census of distribution: 25 years in the dark. Area, 28(1), $89-95$

Sutton, R.and A. Rafaeli. (1988). "Untangling the relationship between displayed emotions and organisational sales: The Case of Convenience Stores." Academy of Management Journal 31(3):461-487.

Swart, J. and Kinnie, N. (2003). Sharing knowledge in knowledge-intensive firms. Human 
Resource Management Journal, 13, 60-75.

Tempest, S., (1999). Ideas Work: A Study of Learning in Network Contexts: The Case of the UK Television Industry, Nottingham: PhD thesis, University of Nottingham.

Templeton Report (2004). Assessing the Productivity of the UK Retail Sector.

Thomas, R.R., Barr, R.S., Cron, W.L. and Slocum Jr., J.W., 1998. A process for evaluating retail store efficiency: a restricted DEA approach. International Journal of Research in Marketing 15, 487-503

Tijdens, K.and B. Steijn. (2005). The determinants of ICT competencies among employees. New Technology, Work and Employment, 20, 60 - 73.

Timmer, M. and R. Inklaar (2005). Productivity Differentials in the US and EU Distributive Trade Sector: Statistical Myth or Reality?" Groningen: Research Memorandum GD-76, Groningen Growth and Development Centre, April.

Treadgold, A. (1988) Retailing without frontiers. Retail and Distribution Management. 16(6), 8-12.

Tsoukas, H. (1996). The firm as a distributed knowledge system: a constructionist approach. Strategic Management Journal, 17, 11-25.

Tushman, M. and Scanlan, T. (1981). Boundary spanning individuals: their role in information transfer and their antecedents. Academy of Management Journal, 24, 289305.

Tüselmann, H.-J, McDonald, F. and Heise, A. (2003). Employee relations in German multinationals in an Anglo-Saxon setting: toward a Germanic version of the Anglo-Saxon approach? European Journal of IndustrialRelations, 9, 327-349.

Un, C. A. and Cuervo-Cazurra, A. (2004). Strategies for knowledge creation in firms. British Journal of Management, 15, 27-41.

van Ark, B., Inklaar, R. and McGuckin (2003), 'Changing gear': productivity, ICT and service industries: Europe and the United States. In Christensen, J. F. and Maskell, P. (eds.). The Industrial Dynamics of the New Digital Economy. Cheltenham: Edward Elgar.

Walters, D and Laffy, D, 1996. Managing retail productivity and profitability, Macmillan, London.

Wenger, E. (1998). Communities of Practice: Learning, Meaning, and Identity. Cambridge: Cambridge University Press.

Wenger, E. (2000). Communities of practice and social learning systems. Organizations, 7 , 
225-246.

Wood, S. (2002). Organizational knowledge, restructuring and spatial scale: the case of the US department store industry. Tijdschrift voor Economische Sociale en Sociale Geografie, 93, 8-33.

Williamson, O. (1985). The Economic Institutions of Capitalism: Firms, Markets, Relational Contracting. London: Macmillan.

Wong, M.M.L. and Hendry, C. (1999). Employment strategy: comparing Japanese and British retail companies in Hong Kong. Personnel Review, 28 474-490.

Wrigley, N. (2000). The globalization of retail capital: themes for economic geography. In Clark, G. L., Feldman, M. P. and Gertler, M. S. (eds.) The Oxford Handbook of Economic Geography. Oxford: Oxford University Press.

Wrigley, N., Coe, N. M. and Currah, A. (2005). Globalizing retail: conceptualizing the distribution-based transnational corporation (TNC). Progress in Human Geography, 29, 437-457.

Wrigley, N. and Lowe, M. (2007) Introduction: transnational retail and the global economy, Journal of Economic Geography, 7, 337-340. 
Table 1: Alternative measures of productivity

\begin{tabular}{|c|c|c|c|c|c|}
\hline Reference & $\begin{array}{l}\text { Productivity } \\
\text { Measure }\end{array}$ & $\begin{array}{l}\text { Output } \\
\text { Measure }\end{array}$ & Inputs & $\begin{array}{l}\text { Retail } \\
\text { Level of } \\
\text { Analysis } \\
\end{array}$ & $\begin{array}{l}\text { Sample } \\
\text { Details }\end{array}$ \\
\hline McKinsey (1998) & LP, TFP & GM & $\begin{array}{l}\text { L (hours } \\
\text { worked), } \\
\text { space }\end{array}$ & $\begin{array}{l}\text { Food } \\
\text { retailing }\end{array}$ & $\begin{array}{l}\text { UK, US, } \\
\text { France } \\
(1995)\end{array}$ \\
\hline $\begin{array}{l}\text { van Ark et al. } \\
(2003)\end{array}$ & LP & VA & $\begin{array}{l}\text { L (persons } \\
\text { employed), } \\
\text { ICT- } \\
\text { intensity }\end{array}$ & $\begin{array}{l}\text { Industry } \\
\text { level }\end{array}$ & $\begin{array}{l}16 \text { OECD } \\
\text { countries, } \\
\text { inc. UK, US } \\
(1990-2000)\end{array}$ \\
\hline $\begin{array}{l}\text { O'Mahony and de } \\
\text { Boer (2002) }\end{array}$ & TFP, LP & VA & $\begin{array}{l}\text { L (hours } \\
\text { worked), K }\end{array}$ & $\begin{array}{l}\text { Industry } \\
\text { level }\end{array}$ & $\begin{array}{l}\text { US, UK } \\
(1976-2000)\end{array}$ \\
\hline Basu et al.(2003) & TFP & $\mathrm{GO}, \mathrm{VA}$ & $\mathrm{L}, \mathrm{K}, \mathrm{ICT}$ & $\begin{array}{l}\text { Industry } \\
\text { level }\end{array}$ & $\begin{array}{l}\text { UK, USA } \\
(1980-2000)\end{array}$ \\
\hline Doms et al. (2004) & LP & Sales & $\mathrm{L}, \mathrm{K}, \mathrm{ICT}$ & $\begin{array}{l}\text { Retail } \\
\text { stores }\end{array}$ & $\begin{array}{l}\text { US retailing } \\
(1992- \\
1997)\end{array}$ \\
\hline $\begin{array}{l}\text { Haskel and } \\
\text { Khawaja } \\
\text { (2003) }\end{array}$ & LP & VA & $\begin{array}{l}\text { L (Full time } \\
\text { equivalent) }\end{array}$ & Firm level & $\begin{array}{l}\text { UK retailing } \\
(1998-2000)\end{array}$ \\
\hline
\end{tabular}

Note: $\mathrm{LP}=$ labour productivity; TFP = total factor productivity; VA = value added; $\mathrm{GM}=$ gross margin; $\mathrm{GO}=$ gross output; $\mathrm{L}=$ labour; $\mathrm{K}=$ capital; $\mathrm{ICT}=$ information and communication technology 